UDC 821.111-3+821.161.2-3]091

DOI https://doi.org/10.32841/2409-1154.2020.46-3.17

\author{
Kruk A. A., \\ Ph. D. in Philology, \\ Senior Lecturer at the Department of Foreign Languages \\ Kamianets-Podilskyi Ivan Ohiienko National University
}

\title{
THEMATIC CONGENIALITY OF T. HARDY AND I. NECHUI-LEVYTSKYI'S PROSE: LANDSCAPE AND DOMESTIC MOTIVES
}

Summary. The article envisages the comparative study of the works "Jude the Obscure" by T. Hardy and "Mykola Dzheria" by I. Nechui-Levytskyi through the prism of characteristics of thematic kinship, the detection of content dominants, the analysis of coincidences and differences in the embodiment of natural elements, focusing on semantic range, significance of cultural and natural descriptions, features of landscapes, and basic methods of their depiction in general.

Landscape appears in the authors' prose not only as important means of creating a virtual world, but also as one of the components of space and time reflections. In the works "Jude the Obscure" by T. Hardy and "Mykola Dzheria" by I. Nechui-Levytskyi, the theme of nature and settings is closely intertwined with characters' originality. Quite often we notice that the descriptions of nature in the works of English and Ukrainian authors are the embodiment of their fascination with the world beauty that surrounds them and inalienable love to their native land. With the help of various natural phenomena and colorful landscapes, it is possible to judge the author's rethinking and generalization of various aspects in reality. Analysis of these works from the point of view of natural elements is very important, brand-new and will provide an opportunity to analyze the basic principles of artistic depiction of that reality.

The writers' works are very similar to colorful descriptions of settings, including natural phenomena, trees, landscape elements used to depict social situations. Both works are rich in epic and lyrical forms of the vernacular, with the help of which we can imagine the mood and difficult life of characters. The authors reinforce the images of heroes and moods with various descriptions of such literary symbols as well, water, willow, house, which are not just symbols, but hide some certain meanings.

Typological coincidences and differences are found in the descriptions of objective reflections of reality and characters, true reproductions of different spheres of folk life, a detailed analysis of emotional experiences, psychological analysis of problems, causes and actions of characters. In general, despite the unfavorable socio-political conditions, both writers reproduced the spirit of people of that time, raised the moral, ethical, social and political problems.

Key words: comparative analysis, natural elements, landscape, reality, literary symbols.

Problem statement. Landscape is one of the most powerful means of creating a virtual world in certain literary work. It is the most important component of artistic space and time that gives an opportunity to express person's idea of the whole world and himself. Artistic images of nature and striking settings are always rich in spiritual, philosophical and moral content, so they pierce out as a world picture and determine the man's attitude to the whole environment in fiction.

In the works "Jude the Obscure" by Thomas Hardy and "Mykola Dzheria" by Ivan Nechui-Levytskyi, the theme of nature is closely intertwined with the identity of man and is always going to be subjective. Quite often we find descriptions of settings in prose works of both English and Ukrainian writers whereas they convey their point and embody admiration for the beautiful world with an inalienable love to their homeland. Natural phenomena and landscapes become an impetus to rethink and reflect various phenomena of reality. That is to say, with the help of it elegant but colorful plots are being built.

Recent research. The proposed study characterizes the artistic concentration of landscape paintings and their multifunctionality on the material of works "Jude the Obscure" by T. Hardy and "Mykola Dzheria" by I. Nechui-Levytskyi. The phenomena of nature in T. Hardy's prose was studied by such literary critics as H. Bloom [1], J. Bownas [2], D. Brown [3], D. Cecil [4], J. Dillion [5], S. Gatrell [6] and others. I. Nechui-Levytskyi's heritage, where the significant role of nature was considered, was the subject of study for such researchers as I. Denysiuk [7], I. Koliada [8], V. Kononenko [9], K. Sizova [10], M. Tarnavskyi [11], O. Tereshchenko, V. Tkachenko [8], V. Vlasenko [12], etc. However, a comprehensive comparative analysis from the point of view of natural elements in the works of both writers has not yet been carried out. Therefore, this study is important, new and will reveal the basic principles of artistic depiction of life stories and spiritual folk practice.

The purpose of the article is to show the connection of literature with the leading trends of time on the example of T. Hardy and I. Nechui-Levytskyi's prose, envisage the authors' attempts to resolve the contradiction between the ideal and social reality, find out the peculiarities of creative method by analyzing the specifics of the use of landscape by prose writers, reveal the inner state of characters, analyse the artistic originality of landscapes in prose works and their functional purpose in the context of ideological and artistic design.

Main material. In the analyzed works "Jude the Obscure" by T. Hardy and "Mykola Dzheria" by I. Nechui-Levytskyi we constantly meet descriptions of settings, branched structure and variety of semantic transformations of component natural images, symbols of seasons, natural phenomena, trees, landscape elements in particular. In both works natural images primarily depict social situations. Authors are widely regarded as great writers for depicting the circumstances at necessary prerequisite for the disclosure of mental world. 
Thomas Hardy's novel envisages human psychology in social and spiritual aspects, and is rich in descriptions of settings. Even Simon Gatrell notes that "Hardy is a magnificent writer about unconscious Nature" [6, p. 1]. The works of English and Ukrainian writers are very similar in involving philosophical and religious problems. Already in the first part of "Jude the Obscure" we can read a description of little village, or rather hamlet of Marygreen. The author portrays it to the reader in this way: "It was as old-fashioned as it was small, and it rested in the lap of an undulating upland adjoining the North Wessex downs" $[13$, p. 6]. The author describes the village with its ancient history and adds an old well to the description. "Old as it was, however, the well-shaft was probably the only relic of the local history that remained absolutely unchanged" $[13$, p. 6]. Next, the author describes destroyed houses in recent years, cut down forests and old church which was also wrecked: "Above all, the original church, hump-backed, wood-turreted, and quaintly hipped, had been taken down, and either cracked up into heaps of road-metal in the lane, or utilized as pigsty walls, garden seats, guard-stones to fences, and rockeries in the flower-beds of the neighbourhood" [13, p. 6-7]. The author describes with bitter regret how a new building in modern Gothic style was built in place of the church which stood for a century and served people.

Like "Jude the Obscure" the realist fiction "Mykola Dzheria" from its first part starts with a description of small village Verbivka. The village was so named because it was literally drowning in willows. "Серед долин зеленіють розкішні густі та високі верби, там ніби потонуло в вербах село Вербівка" [14, p. 34]. Later, as in the English work, I. Nechui-Levytskyi mentions the village church: "Між вербами дуже виразно й ясно блищить проти сонця біла церква $з$ трьома банями, а коло неї невеличка дзвіниця неначе заплуталась в зеленому гіллі старих груш" [14, p. 34]. This literary prose is rich in epic and lyrical forms of the vernacular, which gives the work a hot vivid color and has profound impact on human consciousness.

In both works, the authors describe water from the first chapters. At the well, Thomas Hardy describes Jude taking water: "After opening the well-cover to begin lowering the bucket he paused and leant with his forehead and arms against the framework, his face wearing the fixity of a thoughtful child's who has felt the pricks of life somewhat before his time" $[13$, p. 5]. With the help of this description, we can already imagine the mood and difficult life of this boy. With the well's description the author reinforces the protagonist's image and his depressive mood: "The well into which he was looking was as ancient as the village itself, and from his present position appeared as a long circular perspective ending in a shining disk of quivering water at a distance of a hundred feet down. There was a lining of green moss near the top, and nearer still the hart'stongue fern" $[13$, p. 5-6].

From ancient times water was considered as a source of all life. In "Pre-Christian beliefs of Ukrainian people" Ivan Ohiienko (Metropolitan Hilarion) remarks that people believed that water brings great well-fair to man and nature, "бо оживлює землю й робить iii плодючою" [15, p. 40]. In the work of Thomas Hardy, Jude drew water from a well, and in "Mykola Dzheria" author describes the scene when Mykola first saw Nymydora, who drew water from the river Rastavytsia. Water has always been a natural symbol of purity. The author aptly hints at the purity of Nymydora's persona: "Перед ним (Миколом) блищала зелена левада, мліла проти сонця чиста вода в Раставиці" [14, p. 36]. Water symbolizes youth, health, let's remember, at least, a proverb “Будь багатий, як земля, а здоровий, як вода!" (Be as rich as earth and as healthy as water). "Вода має велику силу" notes Ivan Ohiienko [15, p. 40]. As a symbol of courtship and love, water is often envisaged as concretized, symbolizing the girl. Thus, I. Nechui-Levytskyi depicts clear water symbolizing a cute and pretty girl.

By the way, Jude's acquaintance with his future wife Arabella Donn also occured near the water, namely the stream. The only difference in authors' storylines was that Arabella with girls at her first meeting with the protagonist Jude rinsed pieces of flesh, the characteristic parts of barrow-pig in water: "On the further side of the stream stood a small homestead, having a garden and pigsties attached; in front of it, beside the brook, three young women were kneeling, with buckets and platters beside them containing heaps of pigs' chitterlings, which they were washing in the running water" [13, p. 42]. The scene of the first acquaintance had already shown us the character of Arabella. We could suppose that she was a liar, rude in behavior, boastful, tactless, a kind of cruel (as we would learn later from the text). She was "fine dark-eyed girl, not exactly handsome, but capable of passing as such at a little distance, despite some coarseness of skin and fibre" [13, p. 42]. Then the author described her in more detail, pointing to her brutality: "She had a round and prominent bosom, full lips, perfect teeth, and the rich complexion of a Cochin hen's egg. She was a complete and substantial female animal - no more, no less" [13, p. 42].

That is, from this scene the reader can judge that the couple was not destined to be together for a long time. Already here we can judge that Arabella is not his partner. This is not the person with whom he can share his ideas and knowledge. In this regard, Simon Gatrell stressed: "Hardy seems to want to say that Jude Fawley knows despair and death because of his own nature, because society works to exclude him, because he was predestined to, because senseless circumstance wills that he should, because he met an unsuitable woman" [6, p. 2-3]. Arabella even can be named a foil character in the story as she is usually minor character and has traits opposed to Jude's.

I. Nechui-Levytskyi in "Mykola Dzheria" constantly permeates the work with artistic images of nature, namely willows: "Yci вулиці в Вербівці ніби зумисне обсаджені високими вербами: то поросли вербові кілки тинів. Усе село наче в розкішних алеях" [14, p. 35]. From ancient times in Ukraine willow is considered as sacred plant. The willow is a female symbol of the world tree, the personification of woman's mysterious power, fertility and motherhood. The author further adds: "Як залле Вербівку літне палке сонце, як засипле ії зверху золотом та сріблом сонячне марево, то вся кучерява долина здається залитою буйними зеленими морськими хвилями, що десь набігли з моря, й залили, й затопили долину" [14, p. 35]. Willow is always associated with water, so people have said since ancient times "Там криниця, де вербиця" (There's a well, where is a willow). This tree symbolizes health and life. According to ancient beliefs "верба відганяс від хати злі сили й хвороби" designates Ivan Ohiienko $[15$, p. 55]. In general, the willow was considered as life ancestor.

Such and similar literary symbols, scattered in great wealth in the storyline of Ukrainian writer, have something more real than just symbols or ceremonial forms. We often come across a symbolic image of a house in "Mykola Dzheria": "Коло самої Раставиці, стояла хата старого Петра Джері. Невеличка хата насилу 
світилась білими стінами через густий рядок верб. Коло хати pic невеликий старий садочок" [14, p. 35]. In the symbolized image of house, the author embodies family life, a generalized expression of family idyll. In general, as Vitaliy Kononenko says, ideas and visions are connected with the house "в основі своїй безумовно вказують на 'родинність', 'домашнє вогнище”, $[9$, p. 207]. If a young willow symbolizes vitality, fertility, health, protects against disease, natural disaster, evil spirits, then the old willow is associated with something bad.

In both plots, the main characters are young men. In "Jude the Obscure" protagonist is Jude Fawley, and in "Mykola Dzheria" the main character is Mykola Dzheria. However, the big difference between these two persons is their characters. Jude is a highly sensitive person, an introvert, he reacts more sharply than others to society and loves solitude. He subtly senses the world and pays attention to the smallest details. Jude loves nature and animals. The author describes how lovingly Jude fed the rooks in the field: "A magic thread of fellow-feeling united his own life with theirs. Puny and sorry as those lives were, they much resembled his own" $[13$, p. 11]. However, it is difficult for him to live among others, too much effort is spent on empathy, as well as on meeting the standards accepted in society. "He could scarcely bear to see trees cut down or lopped, from a fancy that it hurt them; and late pruning, when the sap was up and the tree bled profusely, had been a positive grief to him in his infancy. This weakness of character, as it may be called, suggested that he was the sort of man who was born to ache a good deal before the fall of the curtain upon his unnecessary life should signify that all was well with him again" [13, p. 13]. Jude was an intellectual identity who strived for harmony and order in everything. He is a deep and thoughtful entity, looks at the world with sober prudence and therefore is not prone to excessive optimism and admiration for external features, because he always tries to get to the bottom of things. Jude is a gifted man, he dreamed to be D.D. or "even a bishop by leading a pure, energetic, wise, Christian life" [13, p. 40].

Instead, Mykola Dzheria was completely different. "Чорне волосся на голові, чорні рівні брови дуже виразно блищали на білій свиті. Запалене лице було гарне, але дуже молоде. Червоний пояс обвивавсь, наче гадюка, кругом тонкого стану" $[14$, p. 36]. I. Nechui-Levytskyi shows us the figure of Ukrainian peasant-rebel Mykola Dzheria, a man of freedom, tireless, energetic, high morals. After all, he is not afraid of anyone or anything, is very decisive in his behavior, and often campaigns for social causes and issues: "Микола 3 товаришами засів на засідки на леваді між вербами, і саме тоді, як осавула вертався од пана, вони вискочили з-за кущів, простягли осавулу й дали йому півсотні добрих київ" [14, p. 62]. Mykola Dzheria hates oppressors. He does not want to obey either the lord or the ataman. Ihor Koliada and Oleksandr Tereshchenko confirmed that "побутова правдивість у І. Нечуя-Левицького максимальна” [8, p. 167]. In general, the center of I. Nechui-Levytskyi's literary work was the depiction of the situation of Ukrainian peasantry, which suffered from serfdom and aggravating conditions of peasant reform. The authors bitterly add that "велику безодню бачить письменник у відносинах між народом та інтелігенцією в Україні” [8, p. 172]. Like Jude Mykola protests against social injustice. It is referred to as the moral of the story. According to Maksym Tarnavskyi, I. NechuiLevytskyi's greatest evil "криється у серцях людей, а не в їхній національній ідентичності” [11, p. 274].
The cognitive heritage of authors' works is the depiction of their characters and integral spiritual life of individuals. English and Ukrainian writers show the discovery of large number of feelings inherent in different types of personalities and their emotional dramas. The authors reveal significant political and social problems of their time on the material of their prose works. Their literary fiction contains advanced theme such as morality.

Conclusions. Analyzing the works of T. Hardy and I. NechuiLevytskyi, we noticed a significant expansion of their subject matters. Here we met a thematic versatility, stylistic, artistic, figurative and pictorial searchings. The authors expanded thematic horizons in their works. We came across not only images of peasants, but also various intellectuals, officials, and clergy. The form of an objective narrative played an important role, as the authors gave detailed descriptions of portraits of their characters and natural landscapes.

In the novel, Hardy focuses on the social interpretation of the theme and realistic traditions. However, both prose works have their differences and their uniqueness. The bleak plots of both novels mostly always keep readers in suspense. The object and topos of rural prose of T. Hardy and I. NechuiLevytskyi is the life destiny of a man from folk, which in both Ukrainian and English literature appears in the historical space and social entourage. "Т. Гарді переважно зображує долю у статиці заданої простоти, у вимірах усередненої психіки як результату загальноприйнятої буржуазної моралі" [16, p. 123]. Instead, I. Nechui-Levytskyi prefers dynamics of "стихійного протесту селянина проти соціальної несправедливості у гнобительському суспільстві" [16, p. 123].

In "Jude the Obscure" we clearly trace the correlation of individual and society. This prose work is marked by awareness of social injustice. Reconciled externally to the established laws, internally he does not support such an order and in the culminating part challenges society, that leads to a dramatic result. The Ukrainian writer tried to create the image of the protagonist, who sought to solve modern problems, to find a way to resolve the contradiction between the ideal and social reality. "Mykola Dzheria" encompasses the big-picture of reality and protagonist's strategic choices.

Artistic images of nature in both fiction writings are rich in spiritual, philosophical and moral contents. Both Thomas Hardy and Ivan Nechui-Levytskyi in their works show the direct dependence of their social, moral and religious ideas on conditional existence in society.

\section{References:}

1. Bloom H. Bloom's Modern Critical Views. Thomas Hardy. USA, N. Y. : Infobase Publishing, 2010. 196 p.

2. Bownas J. Thomas Hardy and empire: the representation of imperial themes in the work of Thomas Hardy. USA, Burlington : Ashgate Publishing, 2012. $174 \mathrm{p}$.

3. Brown D. Thomas Hardy. London : Longmans, Green, 1954. 196 p.

4. Cecil D. Hardy the Novelist: An Essay in Criticism. London : Constable, 1943. $157 \mathrm{p}$.

5. Dillion J. Thomas Hardy: Folklore and Resistance. London : Macmillan Publishers Ltd., 2016. 206 p.

6. Gatrell S. Thomas Hardy and the proper study of mankind. Basingstoke, Hampshire ; London : The Macmillan Press LTD, 1993. 195 p.

7. Денисюк І.О. Розвиток української малої прози XIX - поч. XX ст. Львів : Академічний Експрес, 1999. 280 с.

8. Коляда I. Ткаченко В., Терещенко О. Вічний бурлака нашої літератури. Іван Нечуй-Левицький. Життєпис. Національно-культурний вимір : монографія. Харків : Вид-во «Ранок», 2019. 448 с. 
9. Кононенко В. Концепти українського дискурсу. Київ-Івано-Франківськ : Плай, 2004. 248 с.

10. Сізова К. Людина у дзеркалі літератури: трансформація принципів портретування в українській прозі XIX - початку XX ст. : монографія. Київ : Наша культура і наука, 2010. 356 с.

11. Тарнавський М. Нечуваний Нечуй. Реалізм в українській літературі. Київ : Лаурус ; Торонто : Наук. т-во ім. Тараса Шевченка в Канаді, 2016. 289 c.

12. Власенко В. Художня майстерність I.С. Нечуя-Левицького. Київ, 1969. $184 \mathrm{c}$.

13. Hardy T. Jude the Obscure. London : Penguin Popular Classics, 1994. $498 \mathrm{p}$.

14. Нечуй-Левицький І.С. Микола Джеря. Зібрання творів : у 10 т. Київ : Наукова думка, 1968. Т. 3. С. 34-142.

15. Іларіон, митрополит. Дохристиянські вірування українського народу : іст.-реліг. монографія. Київ : АТ «Обереги», 1992. 424 с.

16. Крук А.А., Насмінчук Г.Й. Типологія концепту долі у романістиці Т. Гарді й українській прозі доби реалізму (I. Нечуй-Левицький, Панас Мирний, І. Франко) : монографія. Кам'янець-Подільський : ТОВ «Друкарня Рута», 2014. 200 c.

Крук А. А. Тематична спорідненість прози Т. Гарді та І. Нечуя-Левицького: пейзажні й побутові мотиви

Анотація. У статті здійснюється порівняльний аналіз творів «Джуд Непримітний» Т. Гарді та «Микола Джеря» I. Нечуя-Левицького крізь призму характеристики тематичної спорідненості, детекції контентових домінант, проаналізовано спільності та відмінності втілення в них природніх елементів, зосереджено увагу на смисловому діапазоні, культурній значущості описів природи, особливостях пейзажів та основних прийомах їх змалювання загалом.

Пейзаж виступає у прозі авторів не лише як важливий засіб створення віртуального світу, а і як один із компо- нентів відображення простору і часу. Пейзаж дає можливість висловити уявлення персонажа про світ та про самого себе, адже він насичений духовно-філософським та моральним змістом.

У творах обох авторів тема природи тісно переплітається із самобутністю персонажів. Досить часто ми помічаємо, що описи природи виступають втіленням захоплення авторів красою навколишнього світу з невід'ємною любов'ю до свого рідного краю. За допомогою різних явищ природи і колоритних пейзажів можна судити про авторське переосмислення та узагальнення різних сторін дійсності. Аналіз цих творів під кутом зору природніх елементів є важливим, новим й дасть можливість проаналізувати базові принципи художнього зображення тогочасної дійсності.

Твори письменників дуже подібні колоритними описами явищ природи, дерев, елементів ландшафту, що застосовуються для змалювання соціальних ситуацій. Твори багаті на епічні та ліричні форми народної мови, за допомогою чого можна уявити умонастрій та нелегке життя персонажів. Автори посилюють образи героїв та настрої різними описами таких літературних символів, як колодязь, вода, верба, хата, які виступають не просто символікою, а приховують певний зміст.

Типологічні збіги та розбіжності зустрічаються в описах об'єктивного відображення дійсності, правдивому відтворенні всіх сфер народного життя персонажів, в описі характерів, у докладному аналізі емоційних переживань, психологічному аналізі проблем, причин та вчинків героїв. Загалом, незважаючи на несприятливі суспільно-політичні умови, письменники відтворювали дух тогочасного народу, порушували морально-етичні та суспільно-політичні проблеми часу.

Ключові слова: порівняльний аналіз, природні елементи, пейзаж, дійсність, літературні символи. 